\title{
Marketing Orientation in SMEs: Effects of the Internal Environment
}

\section{Richard C. Becherer Diane Halstead Paula Haynes}

\begin{abstract}
Marketing orientation refers to a culture in which organizations strive to create superior value for their customers (and superior performance for the business) by focusing on customer needs and long-term profitability. Some studies have found that firms with a high degree of marketing orientation experience improved performance; others have found mixed or nonsignificant results. The marketing orientation of small businesses has not been thoroughly investigated, however. This study of more than 200 small business CEOs examines the marketing orientation levels of small to medium-sized firms (SMEs) as well as the impact of various internal variables (sales/profit performance, company characteristics, and CEO characteristics) on marketing orientation levels. The results confirm some earlier research on marketing orientation and provide new insights into this important strategic dimension.
\end{abstract}

$\mathrm{T}$ The role of marketing orientation in a firm's business strategy has been debated extensively since the marketing concept was formally introduced 50 years ago. Described as the "implementation of the marketing concept" (Kohli and Jaworski 1990), marketing orientation refers to a culture in which organizations strive to create superior value for their customers (and superior performance for the business) by focusing on customer needs and long-term profitability (Narver and Slater 1990). Specifically, marketing orientation has been defined as the process of: (1) generating marketing intelligence, (2) disseminating marketing intelligence, and (3) responding to marketing intelligence in order to provide superior customer value (Kohli and Jaworski 1990; Narver and Slater 1990). These definitions highlight recent debates about whether marketing orientation encompasses a specific set of organizational behaviors or a type of organizational culture (see Slater and Narver 1995, for example). In any event, marketing orientation has been definitively linked to multiple areas of firm strategy and business performance.

Of the considerable research that has been conducted on marketing orientation, however, very little has focused on the small to mid-sized enterprise. Yet, in SMEs, there is great potential for the CEO's vision to be reflected strongly in the organizational characteristics and operations. Much as an entrepreneurial firm is the expression of the founder's vision and philosophy, so the continued operation of small and mid-sized firms reflects the priorities and marketplace perspective of the company's CEO. As noted by Carson and Gilmore (2000), marketing in SMEs is often "dominated by the inherent characteristics of the entrepreneur/owner/manager of the SME itself" ( $p$. 1). The unique aspects of SMEs and their entrepreneurial founders/managers often lead to a type of "implicit marketing planning" that is less formal, less structured, and less sequential than traditional marketing frameworks. Informal, intuitive and context-specific marketing practices that reflect the style and influence of the entrepreneurs tend to evolve (Carson 1993).

In addition, much of the existing research on marketing orientation has focused on the external environment rather the internal environment. For example, industry characteristics such as market turbulence or market growth, competitive conditions such as hostility or intensity, and even the degree of technological turbulence have all been examined. The internal environment has been investigated, but the characteristics studied were more suited to large-firm research such as decentralization (Jaworski and Kohli 1993; Pelham and Wilson 1996), formalization (Jaworski and Kohli 1993; Pelham and Wilson 1996), and interfunctional coordination/connectedness (Jaworski and Kohli 1993; Atuahene-Gima 1996; Pelham and Wilson 1996; Gatignon and Xuereb 1997; Han, Kim, and Srivastava 1998). More recently Coviello et al. (2000) investigated size-related differences in how SMEs approach such marketing activities as market planning and market performance. Their results were mixed regarding the effect of size, and they point out the importance of learning more about when and why differences do exist between different size firms. In general, however, few internal factors focusing on the SME, and especially the firm leader, have been investigated relative to marketing orientation.

Our research objective, therefore, is to explore the circumstances in the internal environment under which marketing orientation varies in small and mid-sized firms. Specifically, what levels of marketing orientation are observed in SMEs? In addition, under what company, leader, and performance characteristics are low marketing orientation levels observed? Under what conditions will marketing orientation remain high? The specific internal variables examined include performance of the SME in 
terms of sales and profit, characteristics of the company (e.g., size and scope of the business), and characteristics of the company CEO such as age, education, decisionmaking style, and entrepreneurial experience.

\section{Theoretical Background}

Marketing orientation has been linked to business outcomes such as sustainable competitive advantage (Narver and Slater 1990; Pelham and Wilson 1996), profitability (Narver and Slater 1990), new product innovation (Lukas and Ferrell 2000), and overall firm performance (Jaworski and Kohli 1993; Slater and Narver 1994). Recently, Pelham (2000) in one of the few studies focusing on SMEs, found marketing orientation to have a strong relationship with performance. While the importance of marketing orientation in determining various aspects of business performance has been well documented, some inconsistent findings have still emerged. For example, Greenley (1995) found no direct influence of marketing orientation on performance. Pelham and Wilson (1996) found that while marketing orientation did influence new product success, it did not impact growth or market share, two critical marketing performance measures.

The problem of inconsistent findings is compounded when firm size, strategy, and other environmental characteristics are examined. Large firms have been noted for their marketing responsiveness (Day and Nedungadi 1994). Yet small firms should be better suited to the adoption of a marketing orientation since their greater response speed (Katz 1970), flexibility (Feigenbaum and Karnani 1991), and ability to exploit marketing niches (Caroll 1994) have all been noted. Do small firms exhibit high levels of marketing orientation, and if so, under what conditions? This issue deserves additional study, as the limited research on small firms does not attempt to identify the antecedents of marketing orientation.

Marketing knowledge is based on the theory-building research process that examines an issue from initial theoretical concept, through measurement design and testing, to specific moderator and outcome examinations. To clarify the existing contribution of marketing orientation research through these stages, the following classification is useful:

- Initial conceptual development: Studies in this stage examine theoretical/conceptual issues and the development of various research frameworks (e.g., Kohli and Jaworski 1990; Narver and Slater 1990; Slater and Narver 1995).

- Measurement development: Translation of the concept into empirically testable measurement tools and validation (Morris and Paul 1987; Miles and Arnold 1991; Kohli, Jaworski, and Kumar 1993).
- Concept testing: These studies include examination of-

-antecedents of marketing orientation (Jaworski and Kohli 1993; Atuahene-Gima 1996; Pelham and Wilson 1996; Gatignon and Xuereb 1997; Han, Kim, and Srivastava 1998; Harris 1999; Voss and Voss 2000 );

- performance outcomes of marketing orientation (Narver and Slater 1990; Jaworski and Kohli 1993; Slater and Narver 1994; Atuahene-Gima 1996; Pelham and Wilson 1996; Gatignon and Xuereb 1997; Han, Kim, and Srivastava 1998; Lukas and Ferrell 2000; Voss and Voss 2000);

-moderators of the marketing orientation-performance relationship (Jaworski and Kohli 1993; Slater and Narver 1994; Atuahene-Gima 1996; Pelham and Wilson 1996; Becherer and Maurer 1997; Gatignon and Xuereb 1997; Han, Kim, and Srivastava 1998); and

-the impact of marketing orientation and various marketing practices in alternative organizations such as small or mid-size firms (Pelham 1997, 2000; Horng and Chen 1998; Carson and Gilmore 2000) and even nonprofit, artistic environments (Voss and Voss 2000).

This research process classification highlights the need for additional studies examining the impact of marketing orientation within the context of SMEs. As the internal environmental and internal context of the SME has received less research attention, this is an area that is particularly important to examine. Since this study will focus on this last stage in the research classification-marketing orientation among small and mid-size firms - a review of the limited literature in this area follows.

\section{Marketing Orientation in SMEs}

Research on marketing orientation has been concerned primarily with large U.S. firms; relatively few studies have been conducted that are specific to small and mediumsized businesses. In an early study, Peterson (1989) found that most small U.S. manufacturing businesses adopt either a production orientation or, secondarily, a sales orientation, rather than a marketing orientation. These findings were later confirmed in a study of small exporting firms conducted by Sriram and Sapienza (1991). Pelham (2000) found a negative relationship between firm size and marketing orientation. He noted that small firms that are marketing-oriented could enjoy a potential sustainable competitive advantage since they have simpler organizational structures, more flexibility and adaptability, and a greater capacity for speed and innovation. Barrett and Weinstein (1998) argue, however, that small firms have limited resources and little margin for error. This would indicate that SME's marketing orientation levels may be 
affected. Thus, the existence or level of marketing orientation among SMEs should continue to be investigated. Furthermore, the business performance of small/mid-sized firms with various marketing orientation levels should be examined. Accordingly, we propose the following hypotheses:

Hypothesis 1: Marketing orientation levels do not vary among SMEs across company characteristics such as firm size, age, scope, or competitive advantage.

Hypothesis 2: Marketing orientation levels do not vary among SMEs across business performance levels such as change in sales or profits.

Of additional interest would be whether leader characteristics such as CEO education or experience levels would influence marketing orientation levels. For example, Horng and Chen (1998) found that the marketing experience and formal education of Taiwanese top managers significantly affected marketing orientation levels of small manufacturing concerns. Leadership style, however (which they classified as "people orientation"), had very mixed effects on various components of marketing orientation. Barrett and Weinstein (1998) argued that certain internal variables such as entrepreneurship behavior and other internal influences may be more important influences than external variables (such as industry characteristics or competitive hostility) because internal variables are, ultimately, more controllable than external variables. Thus, characteristics of the SME and the SME leaders should be examined in relation to marketing orientation. Therefore, the following exploratory research hypotheses are proposed:

Hypothesis 3: Marketing orientation levels among SMEs will not vary across leader characteristics such as CEO age, gender, or education.

Hypothesis 4: Marketing orientation levels among SMEs will not vary across leader decision-making style.

Hypothesis 5: Marketing orientation levels among SMEs will not vary across the entrepreneurial experience of the leader.

\section{Methodology}

\section{Sample and Data Collection}

The data was collected by questionnaires mailed to 683 small business CEOs located in large mid-western metropolitan areas. These respondents were drawn from a list of firms that had previously participated in a university Small Business Institute consulting program over a 12-year period. Many of these firms had grown and matured during that time. To attempt to make the sample more comprehensive, over several years, additional start-up and small businesses were added to the mailing list.

The data collection procedure included an initial postcard alerting the respondent to the study and two subsequent mailings of the questionnaire and return envelope. There were 215 usable responses, for a response rate of 31 percent. Nonresponse bias was investigated by comparing the first 25 percent of the responses with the last 25 percent of the responses received. No significant differences were found for several demographic characteristics such as the age of the firm or the number of the employees in the firm. A t-test was also used to compare the early and late respondents for each of the research variables, and this analysis revealed no significant differences.

Of the respondent company CEO/presidents, 79 percent was male, and 21 percent was female. The companies they headed had median sales of $\$ 3.5$ million. Founded an average of 15 years ago, these firms had a median of 22 employees. The scope of operation of these firms ranged from local to international, with sales of $\$ 10$ million at the 75th percentile.

\section{Measures}

Marketing Orientation. An 11-item scale consisting of items originally developed by Morris and Paul (1987) and adapted by Miles and Arnold (1991) was used to measure marketing orientation. It has demonstrated very high internal consistency in prior research and exhibited a coefficient alpha of .77 in this study. The items in this scale reflect such factors as the company president's perspective on whether his or her firm "regularly performs marketing research" or "commonly uses customers as a source of new ideas." This measure is shown in Figure 1.

Since there has been limited study of marketing orientation in SMEs, the authors selected aspects of the internal environment that intuitively should influence the extent of marketing orientation in a small company. Additionally, factors were identified that could be investigated via responses provided by a small company president.

Company Characteristics. The five characteristics of the organizations were measured by asking the company presidents to classify their company into the appropriate category for each of the five company characteristics: number of full-time employees, perceived competitive advantage, scope of the business, age of the company, and company sales. The categories for each variable are presented in Table 1.

Company Performance. The performance of the company relative to both profit and sales was measured by asking the respondent company president what percentage change had occurred in sales and profit over the past three years. Due to the wide variation (from very negative 


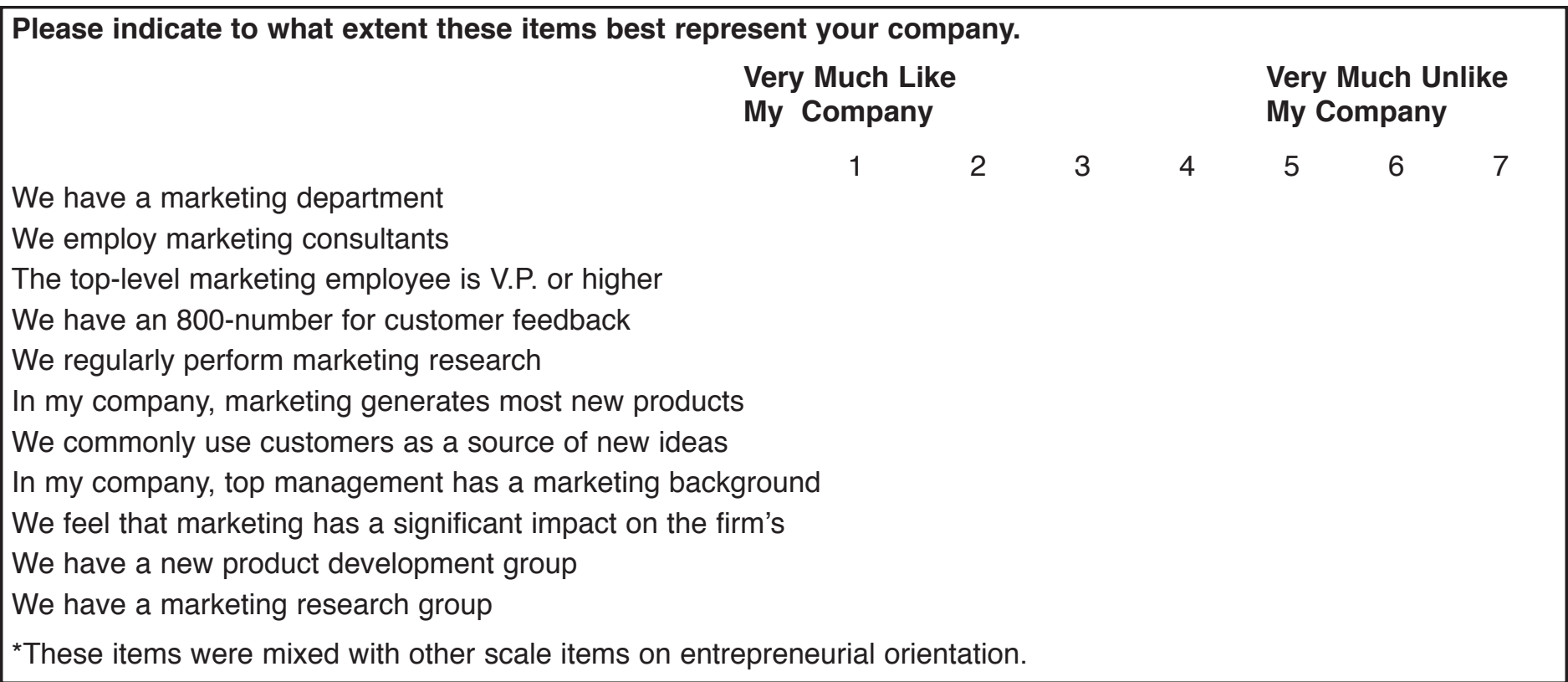

Figure 1. Marketing Orientation Scale Items ${ }^{*}$

\begin{tabular}{|c|c|c|c|c|}
\hline \multicolumn{5}{|c|}{$\begin{array}{c}\text { Table } 1 \\
\text { Analysis of Variance for Company Characteristics }\end{array}$} \\
\hline & Variable & $\begin{array}{c}\text { Mean } \\
\text { Marketing Orientation }\end{array}$ & F-Ratio & Significance \\
\hline $\begin{array}{l}\text { Number of Full-time } \\
\text { Employees }\end{array}$ & $\begin{array}{r}1 \text { to } 9 \\
10 \text { to } 19 \\
20 \text { to } 99 \\
100+\end{array}$ & $\begin{array}{l}34.65 \\
39.24 \\
42.58 \\
45.10\end{array}$ & 6.54 & 0.00 \\
\hline Competitive Advantage & $\begin{array}{r}\text { unique product } \\
\text { or service } \\
\text { superior customer } \\
\text { service } \\
\text { excellent product } \\
\text { mix } \\
\text { operating cost } \\
\text { price } \\
\text { other }\end{array}$ & $\begin{array}{l}41.42 \\
39.41 \\
44.88 \\
32.80 \\
36.10 \\
42.71\end{array}$ & 1.00 & 0.42 \\
\hline Scope of the Business & $\begin{array}{r}\text { local } \\
\text { state wide } \\
\text { regional( multi-state) } \\
\text { national } \\
\text { international }\end{array}$ & $\begin{array}{l}32.76 \\
40.52 \\
42.49 \\
44.84 \\
46.29\end{array}$ & 9.58 & 0.00 \\
\hline Age of Company & $\begin{array}{r}0 \text { to } 4 \\
5 \text { to } 14 \\
15 \text { to } 49 \\
50+\end{array}$ & $\begin{array}{l}40.61 \\
40.79 \\
38.86 \\
40.73\end{array}$ & 0.30 & 0.83 \\
\hline Company Sales & $\begin{array}{r}\$ 0-499 \\
500-1999 \\
2000-9999 \\
10000+\end{array}$ & $\begin{array}{l}36.93 \\
36.25 \\
40.76 \\
43.80\end{array}$ & 4.04 & 0.01 \\
\hline
\end{tabular}


to very positive), these responses were grouped into four categories for both variables.

Company President Characteristics. The respondent company presidents were asked to indicate their gender and the appropriate category for their age and education.

Decision-Making Style. Respondents were asked whether they make, share, or do not make decisions on both day-to-day and long-term issues. Daily issues were characterized as such things as issuing credit or purchasing, and long-term decisions were described as strategic areas like expansion or major new financial commitments.

Entrepreneurial Experience. The entrepreneurial experience of the company president was assessed in two ways. The CEO respondents were asked to indicate their ownership status in the company. The choices were: just manage the company, started the company, purchased the company, inherited the company, or "other" as ownership status. "Other" may include presidents who have stock options or other "earn in" provisions. As a second variable, each respondent was asked how many businesses he or she had started.

\section{Results}

To examine the influence of organizational characteristics on the marketing orientation of SMEs, ANOVA was used to analyze five different internal organizational characteristics as independent variables, with marketing orientation as the dependent variable. These results are presented in Table 1. As is indicated in the results, three significant differences were identified in these five company characteristic variables.

Marketing orientation was significantly different across the size of the organization as measured by the number of employees $(p=.00)$. Interestingly, as the company size increased (from small companies with 9 or fewer employees to those with 100 or more employees), the level of marketing orientation increased. Significant differences were found again when company size was measured by sales level $(p=.01)$. When comparing the smallest sales volume companies with the largest, with only slight variation, the larger companies tended to exhibit more marketing orientation than the smaller companies.

While there were no significant differences in the marketing orientation of companies based on their reported competitive advantage focus $(p=.42)$, the pattern of results is suggestive. A differentiation strategy appears to be associated somewhat with higher levels of marketing orientation as compared to a more price focused strategy. Scope of the business did produce significant differences $(p=.00)$. Companies that were local showed the least amount of marketing orientation, and as the scope of the company operations got broader (i.e., state, regional, national, and international), the marketing orientation at each level increased $(p=.00)$. The number of years in operation was not a significant characteristic, however $(p=.83)$.

The analyses presented in Table 1 provide some evidence that there is a difference in marketing orientation over different company characteristics. Hence, $\mathrm{H}_{1}$ is rejected, indicating that an increase in a company's marketing orientation can be anticipated as the size or scope of their operations increase.

The performance of a company and its marketing orientation are investigated in Table 2. Potential differences in marketing orientation relative to the change in profit and change in sales over the preceding three-year period were examined. The analysis of variance for change in sales was significant. Companies with more favorable changes in sales demonstrated more marketing orientation than firms with less satisfactory sales performance over the preceding three years $(p=.02)$.

Although the ANOVA examining the change in profits was marginally significant $(p=.10)$, the marketing orientation/performance relationship was not completely clear. While in general, firms with a more favorable change in profits exhibited more marketing orientation, there was a slight dip in marketing orientation comparing firms with

\begin{tabular}{|c|c|c|c|c|}
\hline \multicolumn{5}{|c|}{$\begin{array}{c}\text { Table } 2 \\
\text { Analysis of Variance for Company Performance }\end{array}$} \\
\hline & $\%$ Change & $\begin{array}{c}\text { Mean } \\
\text { Marketing Orientation }\end{array}$ & F-Ratio & Significance \\
\hline $\begin{array}{l}\text { Company Change in Profits } \\
\text { Over the Past } 3 \text { Years }\end{array}$ & $\begin{array}{r}-100 \text { to }-1 \\
0 \\
1 \text { to } 24 \\
100+\end{array}$ & $\begin{array}{l}37.81 \\
36.08 \\
39.37 \\
44.58\end{array}$ & 1.97 & 0.10 \\
\hline $\begin{array}{l}\text { Company Change in Sales } \\
\text { Over the Past } 3 \text { Years }\end{array}$ & $\begin{array}{r}-100 \text { to }-1 \\
0 \\
1 \text { to } 24 \\
25 \text { to } 99 \\
100+\end{array}$ & $\begin{array}{l}31.82 \\
37.70 \\
39.90 \\
42.45 \\
42.83\end{array}$ & 3.16 & 0.02 \\
\hline
\end{tabular}




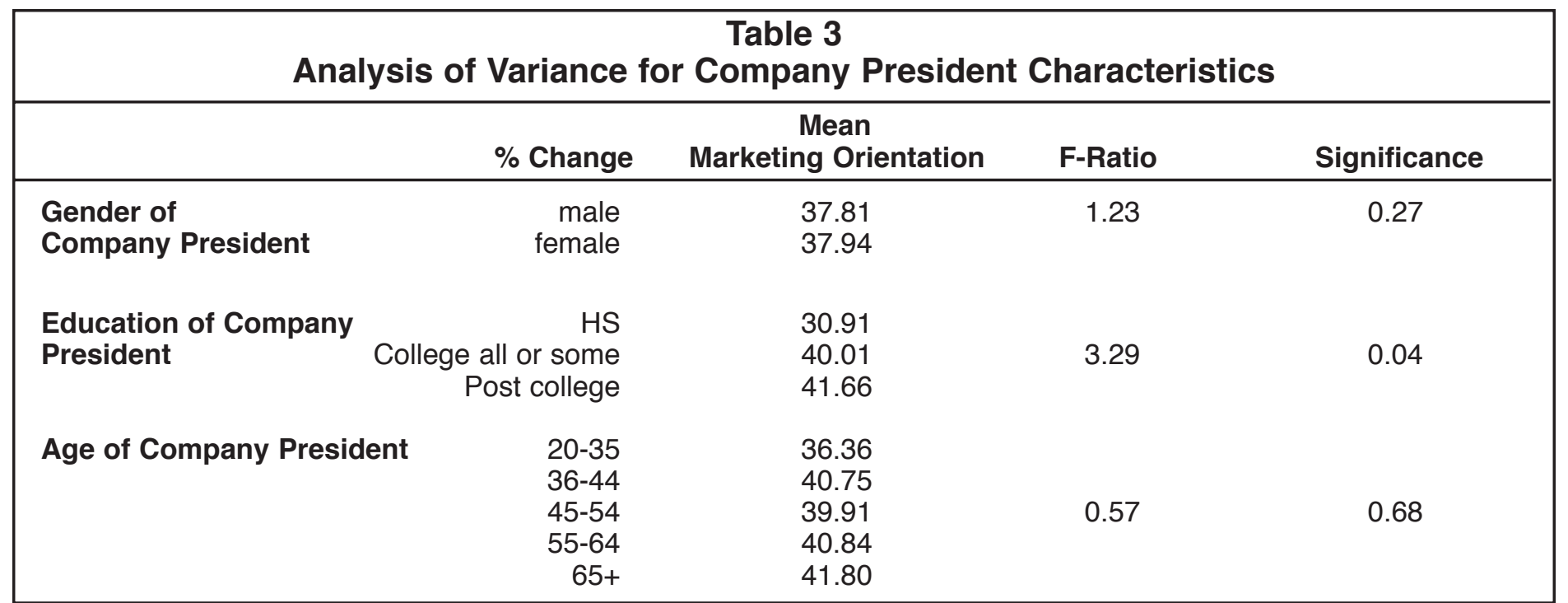

static profit performance over the past three years. Based upon the overall results, however, $\mathrm{H}_{2}$ is rejected; this suggests that higher performing companies tend to have higher amounts of marketing orientation.

Regarding $\mathrm{H}_{3}$, the hypothesis dealing with the marketing orientation of the company relative to the personal characteristics of the leader, the analysis is presented in Table 3. The personal characteristic variables that were investigated include the gender, education, and age of the company president. Only education was significant in the analyses of variance that were conducted $(p=.04)$. The data indicated that presidents with less education led companies with significantly less marketing orientation. Since only one of the three analyses was significant, there is insufficient evidence to fully reject $\mathrm{H}_{3}$.

Interestingly, while the pattern of the data regarding the marketing orientation of the company and the decisionmaking style of the leader is the same for both day-to-day decisions and long-term decisions, only for day-to-day decision-making was the relationship significant $(p=.02$; see Table 4). In both decision-making styles, the lowest marketing orientation was found in companies where leaders make all the day-to-day and long-term decisions. This was followed by more marketing orientation when they shared these decisions, and even more when they are not involved in these decisions at all. The differences, however, were not significant for the long-term decisions $(p=.44)$, suggesting that $\mathrm{H}_{4}$ can be rejected only tentatively. The somewhat indeterminate results of both $\mathrm{H}_{3}$ and $\mathrm{H}_{4}$ suggest that further research on these variables is needed.

For the fifth hypothesis involving the marketing orientation of the company and the entrepreneurial experience of the company leader, the data is presented in Table 5. Two measures of entrepreneurial experience were utilized, and both were significant.

While it is clear from the data in Table 5 that the marketing orientation of a company varies depending on the entrepreneurial experience of the leader, the results also suggest some unanticipated but interesting findings. Managers (i.e., with no ownership) and those who inherited their ownership demonstrated the lowest levels of marketing orientation. In contrast, the highest level of marketing orientation was associated with company presidents with stock options and "buying-in" ownership potential. Falling in the middle with respect to marketing orientation were those who started or purchased the business. The fact that the highest level of marketing orientation was associated with more sophisticated ownership mechanisms such as stock options may provide some insights into these results. This group may include a more experienced set of company leaders. The lower levels of market-

\begin{tabular}{|lrrrr|}
\hline \multicolumn{5}{c}{ Analysis of Variance for Company President Decision-making Style } \\
\hline & \% Change & Marketing Orientation & F-Ratio & Significance \\
\hline Day-to-Day & make & 36.96 & \\
Decisions & share & 42.07 & \multirow{2}{*}{0.02} \\
& do not make & 43.43 & & 0.44 \\
Long-term & make & 39.03 & 0.84 & \\
Decisions & share & 41.14 & & \\
& do not make & 46.00 & & \\
\hline
\end{tabular}




\begin{tabular}{|lrrrr|}
\hline \multicolumn{5}{|c}{ Analysis of Variance Entrepreneurial Experience of Company President } \\
\hline & \% Change & Marketing Orientation & F-Ratio & Significance \\
\hline Ownership Status of & started & 39.61 & & \multirow{2}{*}{0.04} \\
Company President & purchased & 41.49 & 2.64 & \\
& inherited & 37.80 & & \\
& other own & 56.60 & & \\
Number of Businesses & manager & 38.32 & \\
Started by Company & 0 bus. started & 38.81 & \\
President & 1 bus. started & 36.17 & \\
& 2-3 bus. Started & 44.98 & & \\
\end{tabular}

ing orientation for those who had initiated or purchased their firms may reflect a less experienced leader group.

Similarly, the ANOVA for marketing orientation and the number of prior businesses that the leader has started is also significant. While company presidents who had experience with multiple previous start-ups demonstrated higher levels of marketing orientation, no clear pattern was seen in the past entrepreneurship experience/marketing orientation relationship. For example, firm leaders with between two and three previous start-ups had higher levels of marketing orientation than those who had initiated four or more businesses.

This second category of entrepreneurial experience is based on the number of start-ups, however, not the number of sustained ventures the leader has been involved with. It is possible that an "idea generator" type of founder is prevalent in the group that reported four or more previous launches. Marketing orientation may be most critical in sustaining a venture. These founders may be more involved in the start-up phase than in sustaining the enterprise. This may account for this group's lower level of marketing orientation, even with greater apparent entrepreneurial experience. Based on the analysis, however, $\mathrm{H}_{5}$ can be rejected.

\section{Discussion and Implications}

Better insights into the influences that organizational and leader characteristics have on marketing orientation can lead to more effective marketing practices. For small to medium-sized enterprises, these factors have been less frequently examined. This study was an effort to make such an analysis, and several patterns emerged.

\section{Theoretical Implications}

Previous studies (Slater and Narver 1995; Harris 1999, for example) suggest that the internal characteristics of an organization can play a determining role in implementing an organization-wide marketing orientation. This study's overall findings support that perspective in SMEs. Certain key organizational and leader characteristics were associated with significant differences in the marketing orientation of the firms in the study.

The pattern of differences suggested by the findings is also intriguing. On the surface, the findings may suggest that marketing orientation is not stronger in smaller firms. Size of the organization may not be, however, the actual reason for the differences observed. Rather, marketing orientation involves not only the willingness of the firm to gather and disseminate marketing intelligence, but also an organizational culture that is committed to shaping customer value based on marketing intelligence. Both awareness of the contribution marketing intelligence can provide in adding customer value and the resources to put marketing intelligence into effect are necessary. The ability to create and sustain the needed organizational culture and resource infrastructure may be more difficult in smaller firms.

The pattern of differences in marketing orientation associated with day-to-day decision-making may also be considered in this context. As the company leader retained operational decision-making on a day-to-day basis, lower levels of marketing orientation were evidenced. In a larger organization it may be difficult, if not impossible, for the firm president to retain this type of hands-on involvement. In contrast, such involvement might be prevalent in many smaller firms.

While smaller size would appear to offer an advantage in creating a firm-wide responsiveness, fostering such a marketing-oriented culture becomes much more dependent on a single individual: the company president. If the firm's leader is unwilling or unable to relinquish day-to-day decision-making, the organization's culture may also not support the values needed for high levels of marketing orientation. Though more immediately apparent in smaller organizations, top management support for a firm-wide culture that fosters a marketing orientation is critical at any size.

\section{Managerial Implications}

One managerial implication for SMEs involves the type and level of involvement of the CEO on the day-to-day operations of the small business. Clearly, small business 
leaders must learn to delegate day-to-day decision-making once a company grows beyond the start-up and growth phases. The danger of lower levels of marketing orientation being exhibited throughout a firm could be enhanced if CEOs are focused too much on operational issues.

The research findings also suggest that CEO education plays a role in the marketing orientation of SMEs since higher marketing orientation levels were associated with higher levels of CEO education. Small firm leaders, regardless of job pressures or time constraints, should consider continuing executive education programs not only for personal career fulfillment, but also as a logical approach to improving firm performance. The impact of additional education could be especially advantageous if it allows small firm leaders to combat many typical problems associated with SMEs-leadership dependent on the CEO, obsession with growth at all costs, administrative inefficiencies, and poor organizational structure (e.g., Brereton 1974; Lowry and Chapman 2000). In addition, since problems in sales/marketing recently ranked as the number one business problem of small and mid-sized businesses (Lowry and Chapman 2000), greater executive education in this area, including understanding the benefits of and implementation necessary for marketing orientation, could help small companies.

Additionally, this research indicates that marketing orientation is related to both the size and scope of a company's operations. As small and mid-sized firms evolve from start-up ventures and move into the growth, maturity, and rebirth/decline stages, CEOs must begin to place greater emphasis on infusing the SME with his or her innovative behaviors. This includes evolving from traditional marketing companies to "entrepreneurial marketing" organizations (Schindehutte, Morris, and Kuratko 2000). Often referred to as corporate entrepreneurship (Morris and Kuratko 2000), intrapreneurship (Pinchot and Pellman 1999), or corporate venturing (Block and MacMillan 1993), this process of organizational change and renewal relies heavily on a company-wide marketing orientation and activities. For example, the creation of customer value through continuous innovation or leading the company into new markets, products, or technologies will be critical factors for future SME business performance.

\section{Future Research}

The cross-sectional design of this study does not, of course, allow causal inferences. Future longitudinal studies would provide a better understanding of the nature of these relationships. While appropriate to the design, future research might also combine internal self-report measures with other internal and external measures. Such a range of measures would enhance the generalizability of the findings.

Several directions for future research are, however, suggested by these findings. This study examined the potential differences in marketing orientation across internal organizational and leader characteristics in SMEs. Further investigation into the role the organizational leader plays in fostering a firm's marketing orientation could yield valuable insights. For example, the current research must eventually be extended to measure marketing orientation levels of SMEs throughout all stages of the business life cycle, not just at a single point in time. How much (if at all) do marketing orientation levels change over the life of the SME? And how might these changes be impacted, positively or negatively, by other internal characteristics?

Previous research found that a differentiation strategy was associated with higher levels of marketing orientation (Pelham 1997; Homburg, Workman and Krohmer 1999, for example). Although not significant in this study, further examination is needed to determine whether a niche strategy is associated with higher levels of marketing orientation. Since niche/differentiation strategies are often employed by smaller entrepreneurial firms, this has particular relevance for SMEs.

The performance variables used in this study suggested a positive impact on SMEs exhibiting stronger levels of marketing orientation. However, since firms experience differing sales cycles, the time frame between implementing marketing orientation and resultant outcomes may also differ. Incorporating this characteristic into future studies could further clarify the impact of marketing orientation on SME performance.

\section{References}

Atuahene-Gima, K. 1995. An exploratory analysis of the impact of market orientation on new product performance. Journal of Product Innovation Management 12 (September): 275-93.

1996. Market orientation and innovation. Journal of Business Research 35 (February): 93-103.

Barrett, H., and A. Weinstein. 1998. The effect of market orientation and organizational flexibility on corporate entrepreneurship. Entrepreneurship: Theory and Practice 23 (Fall): 57-71.

Becherer, R. C. and J. Maurer. 1997. The moderating effect of environmental variables on the entrepreneurial and marketing orientation of entrepreneur-led firms. Entrepreneurship Theory and Practice 22 (1): 47-58.

Block, Z., and I. MacMillan. 1993. Corporate venturing. Boston: Harvard Business School Press.

Brereton, P. R. 1974. The qualifications for entrepreneurship. Journal of Small Business Management October: 1-22.

Caroll, G. R. 1994. The specialist strategy. California Management Review 26, 3: 126-137. 
Carson, D. 1993. A philosophy of marketing education in small firms. Journal of Marketing Management 9, 2: 189-205.

Carson, D., and A. Gilmore. 2000. Marketing at the interface: Not 'What' but 'how'. Journal of Marketing Theory and Practice 8 (Spring): $1-7$.

Coviello, N. E., R. J. Brodie, and H. J. Munio. 2000. An investigation of marketing practice by firm size. Journal of Business Venturing 15, 5-6: 523-545.

Day, G. S. and P. Nedungadi. 1994. Managerial representation of competitive advantage. Journal of Marketing 53 (January): 37-52.

Feigenbaum, A., and A. Karnani. 1991. Output flexibility-A comparative advantage for small firms. Strategic Management Journal 12: 101-114.

Gatignon, H., and J-.M. Xuereb. 1997. Strategic orientation of the firm and new product performance. Journal of Marketing Research 34 (February): 77-90.

Greenley, G. E. 1995. Forms of market orientation in UK companies. Journal of_Management Studies 32 (January): 47-66.

Han, J. K., N. Kim, and R. K. Srivastava. 1998. Market orientation and organizational performance: Is innovation a missing link? Journal of Marketing 62 (October): 30-45.

Harris, L. C. 1999. Barriers to developing market orientation. Journal of Applied_Management Studies 8 (June): 85-103.6.

Homburg, C., J. P. Workman, and H. Krohmer. 1999. Marketing's influence within the firm. Journal of Marketing 63 (April): $1-17$.

Horng, S., and A. Cheng-Hsui Chen. 1998. Market orientation of small and medium-sized firms in Taiwan. Journal of Small Business Management 36 (July): 79-85.

Jaworski, B. J., and A. K. Kohli. 1993. Market orientation: Antecedents and consequences. Journal of Marketing, 57 (July): 53-70.

Katz, R. I. 1970. Cases and concepts in corporate strategy. Englewood Cliffs: Prentice-Hall.

Kohli, A. K., and B. J. Jaworski. 1990. Market orientation: The construct, research propositions, and managerial implications. Journal of Marketing 54 (April): 1-18.

Kohli, A. K. B. J. Jaworski, and A. Kumar. 1993. MARKOR: A measure of market orientation. Journal of Marketing Research 30 (November): 467-77.

Lowry, J. R., and J. D. Chapman. 2000. Critical business problems and advisors. Journal of Small Business Strategy 11, 1: 64-71.

Lukas, B. A. and O. C. Ferrell. 2000. The effect of market orientation on product innovation. Journal of the Academy of Marketing Science 28, 2: 239-47.

Miles, M. P., and D. R. Arnold. 1991. The relationship between marketing orientation and entrepreneurial orientation. Entrepreneurship: Theory and Practice 15, 4: 49-65.

Morris, M., and D. Kuratko. 2000. Corporate entrepreneurship: Entrepreneurial development within organizations. Dallas: Harcourt Publishers.

Morris, M. H., and G. W. Paul. 1987. The relationship between entrepreneurship and marketing. Journal of Business Venturing 2: 247-259.

Narver, J. C., and S. F. Slater. 1990. The effect of market orientation on business profitability. Journal of Marketing 54 (October): 20-35.

Pelham, A. M. 1997. Mediating influences on the relationship between market orientation and profitability in small industrial firms. Journal of Marketing Theory and_Practice 5 (Summer): 55-76.

2000. Market orientation and other potential influences on performance in small and medium-sized manufacturing firms. Journal of Small Business Management (January): 48-67.

Pelham, A. M., and D. T. Wilson. 1996. A longitudinal study of the impact of marketing structure, firm structure, strategy, and market orientation culture on dimensions of small-firm performance. Journal of the Academy of Marketing Science 24, 1: 27-43.

Peterson, R. T. 1989. Small business adoption of the marketing concept vs. other business strategies. Journal of Small Business Management (January): 38-46. 
Pinchot, G., and R. Pellman. 1999. Intrapreneuring in action. San Francisco: Berrett-Koehler Publishers.

Schindehutte, M., M. Morris, and D. Kuratko. 2000. Triggering events, corporate entrepreneurship and the marketing function. Journal of Marketing Theory and Practice 8 (2): 18-30.

Slater, S. F., and J. C. Narver. 1994. Does competitive environment moderate the market orientation-performance relationship? Journal of Marketing 58 (January): 46-55.

1995. Market orientation and the learning environment. Journal of Marketing 59 (July): 63-74.

Sriram, V., and H. J. Sapienza. 1991. An empirical investigation of the role of marketing for small exporters. Journal of Small Business Management (October): 33-43.

Voss, G. B. and Z. Voss. 2000. Strategic orientation and firm performance in an artistic environment. Journal of Marketing 64 (January): 67-83.

\section{$+2$}

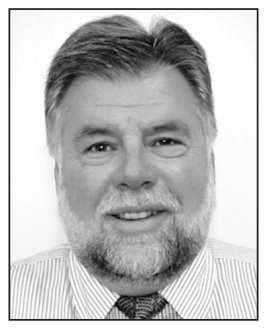

Richard C. Becherer (Richard-Becherer@utc.edu) holds the Clarence E. Harris Chair of Excellence in Business and Entrepreneurship at the University of Tennessee at Chattanooga. He has had extensive experience both as an academic and as an entrepreneur. He cofounded one of the first for-profit health maintenance organizations in the United States, and has also been involved in several other business start-ups, including a marine business and a plastic injection molding business. Dr. Becherer received his doctorate from the University of Kentucky and primarily teaches entrepreneurship courses. He has been published in numerous journals, including Entrepreneurship Theory and Practice, Journal of Small Business Management, Journal of Marketing, and Decision Sciences. He was the 1993 winner of the Coleman Foundation Award for the best research paper at the 1992 University of Illinois-Chicago American Marketing Association Research Symposium on Marketing and Entrepreneurship. In 1998, Dr. Becherer received the Edwin M. Appel Prize presented each year at the Price/Babson College Fellows Program.

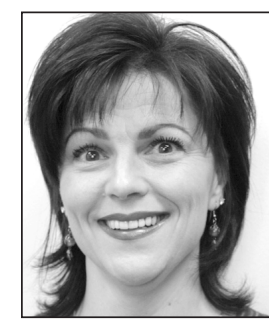

Diane Halstead (Diane-Halstead@utc.edu) is the Mary Harris Distinguished Professor of Entrepreneurship at the University of Tennessee at Chattanooga where she teaches small business management and marketing. She has also held faculty positions at the University of Kentucky and Western Michigan University. Professor Halstead earned a Ph.D. in marketing from Michigan State University and a BBA and MBA in marketing from Western Michigan University. Dr. Halstead's industry experience includes serving as marketing director and account manager for several advertising and public relations agencies. She has also done extensive consulting work for DuPont, American Red Cross, Tennessee Valley Authority, UNUMProvident Corporation, Blue Cross/Blue Shield of Tennessee, and others. Her research has appeared in the Journal of Small Business Strategy, Journal of Marketing Theory and Practice, Journal of the Academy of Marketing Science, Journal of Business Research, International Journal of Research in Marketing, Journal of Services Marketing, and others.

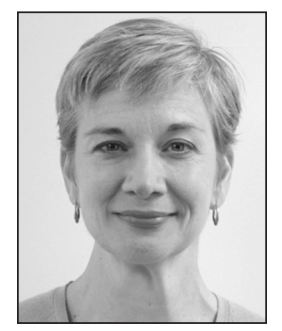

Paula J. Haynes (Paula-Haynes@utc.edu) is the George Lester Nation Professor of Marketing at the University of Tennessee at Chattanooga where she teaches courses in e-marketing, marketing research, and marketing management. She earned her doctor of business administration degree from Mississippi State University. Dr. Haynes has served as a consultant to a variety of for-profit and not-for-profit organizations on quality program implementation, market analysis, and survey procedures. She has published more than 40 articles in journals including Internet Research, Journal of Services Marketing, and Journal of Business and Entrepreneurship. Her current research interests include the effects of job dissatisfaction on the entrepreneurial process and the impact of the Internet on entrepreneurial business activities. 